\title{
From a diversifying workforce to the rise of the itinerant academic
}

\author{
Celia Whitchurch ${ }^{1}$
}

Published online: 19 July 2018

(C) The Author(s) 2018

\begin{abstract}
The literature on the diversification of the higher education workforce has tended to focus on broad brush changes to patterns of employment and working conditions. What has been less remarked is ways in which individuals are negotiating the structures and stretching the parameters within which they work, including experience outside higher education. Thus, academic work is also seen in the context of broader opportunities, for instance extended networks that enable individuals to construct new forms of professional capital. Arising from these conditions, two empirical studies, on which this paper draws, demonstrate the emergence of what might be termed itinerant identities. The triggers for these are seen as arising, on the one hand, from a spirit of exploration, that is an intrinsic interest in entering new areas of activity, and, on the other, from a desire for a greater sense of security by keeping a range of options open. The two motivations are not mutually exclusive and are likely to depend on individual circumstances and career stages. It would also appear that, in space outside higher education, individuals may find some of the freedom and autonomy they may feel that they have lost as a result of increased structural requirements including, for instance, workload models and performance assessment.
\end{abstract}

Keywords Academic identity $\cdot$ Academic careers $\cdot$ Career motivations $\cdot$ Institutional processes and structures

\section{Introduction}

An international literature points to changing working conditions and divisions of labour in higher education, for instance Kehm and Teichler (2013), Teichler and Cummings (2015), Galaz-Fontes et al. (2016), and Machado-Taylor et al. (2017). Such conditions include more market-oriented funding regimes for both teaching and research, performance assessment, and

Celia Whitchurch

C.whitchurch@ucl.ac.uk

1 UCL Institute of Education, 20 Bedford Way, London WC1H 0AL, UK 
an increased emphasis on knowledge exchange, the employability of graduates, and the contribution of higher education to social and health agendas (Viale and Etzkowitz 2010; Kweik 2012). This has been accompanied by consideration of the implications of a diversifying workforce, which arises partly as a result of an increase in practice-based disciplines such as the law, the creative arts, health, and business management, in which professionals from practice settings reinforce the curriculum. It also arises from an increasing separation of teaching and research activity, and the targeting of income streams to specific activities (Whitchurch and Gordon 2013a, b; Courtois and O'Keefe 2015; Lama and Jouille 2015; Locke et al. 2016). Such trends have also been identified in Canada, the USA, Australia, and Europe (Coates and Goedegebuure 2010; Cavalli and Moscati 2010; Jones et al. 2012; Musselin 2013; Finkelstein et al. 2016; Kezar and Maxey 2016; Kim 2017). Thus, in the USA, as is now the case in the UK, less than $50 \%$ of academic staff have contracts that formally include both teaching and research.

On the one hand, it has been acknowledged that academic staff are finding ways of accommodating to what many see as more stringent institutional policies arising from market-oriented environments geared to knowledge-based economies. This includes greater mobility by academic staff across disciplines: "acting as institutional entrepreneurs for teaching innovation operating in and deriving identity from the 'multi-versity' as well as their disciplines, or engaging in symbolic boundary crossing of borders of different disciplines" (Deem 2016). On the other hand, the exploration of territories outside higher education has been less remarked. As academia has shifted from being a profession with secure horizons and positional careers with clear milestones en route, to a situation in which individuals feel obliged to exercise agency in future-proofing their careers, this has involved adding experience outwith higher education.

Thus, behind national and international trends in higher education workforce statistics, and formal staffing structures and processes established by individual institutions, lie less well documented initiatives around the career decisions of individuals. These can create a disjunction between formal processes and day-by-day reality, so that individual stories, taken collectively, challenge a common understanding of what it means to be an academic in contemporary environments. Bringing together two empirical studies, outlined below, allowed this to be explored in more detail, and to be theorised in relation to the changing habitus of being an academic, loosening ties to traditional roles, structures, and disciplines, and generating roles that can be used to gain credibility outside the university.

Although the studies focused on the narratives of individuals up to mid-career, these narratives can also be located within a wider literature on early career staff from postdoctoral level onwards (for instance McAlpine and Amundsen 2011; McAlpine et al. 2014). This paper adds to these studies by reviewing understandings of staff at a slightly later stage and, in particular, their prospective concerns and strategies in preparing for less certain futures.

\section{Method}

The paper draws upon studies associated with reports for the UK Leadership Foundation for Higher Education on staffing models and institutional flexibility (Whitchurch and Gordon 2013a, b, 2017) and for the UK Higher Education Academy on meeting the staff development needs of a changing academic workforce (Locke et al. 2016). The projects explored, in the first case, changing models of employment in higher education and, in the second, the careers, 
motivations, and development needs of a more diverse academic workforce. They demonstrated that, on the one hand, top-down initiatives were being taken by institutions to flex structures, such as teaching-only contracts; more flexible reward structures; and partnerships and consortia that enable service sharing arrangements. On the other hand, there was also bottom-up pressure from individuals for more flexible life- and work-styles; a desire for career enrichment; and a portability and transferability of experience (Florida 2010, 2012; Meek et al. 2010; Wilkinson et al. 2016; Moynagh and Worsley 2009). There was therefore pressure for greater flexibility from both institutions and individuals, though often for different reasons.

The qualitative data from both studies was re-analysed, more specifically to understand ways in which formal models of employment were being translated in practice, and ways in which the dynamics characterising a diversifying workforce might be explained. The aim was to show how individuals were negotiating the more fluid environments in which they found themselves, and extending the spaces in which they worked. This included work with professional bodies, practitioner communities, and the private sector, resulting in careers that were less linear and more open-ended. The studies focused on the narratives of individuals up to mid-career, in UK terms from teaching or research fellow to lecturer and senior lecturer. In age terms, this usually represented those up to the age of 45 , including some people who had entered academia late from other professions. Semi-structured interviews were conducted to obtain institutional (from senior and middle managers) and individual (from early and midcareer staff) perceptions of career trajectories, using separate topic guides for senior managers and individual members of staff. Senior and middle managers were asked to give an overview of staff patterns and careers, and the narratives of middle managers in particular demonstrated their significant influence in the adjustment of institutional processes and structures to meet individual needs and strengths. The accounts were also compared with institutional documentation such as human resource strategies, and formal statements about promotion and progression, professional development opportunities, and rewards and incentives.

Both projects were conducted across a range of institutions chosen according to mission, history, and geographic spread across the four countries of the UK. They can be categorised as shown in Table 1.

The profile of those interviewed across the two projects is shown in Table 2.

Of the 56 academic staff in columns $2-5$ in Table 2, 18 identified their discipline as being arts/humanities; 12 as science; 7 as applied science; 13 as social science; and 3 as health/social care (3 in the LFHE study had a professional services background). They were therefore fairly evenly divided between arts, science, and social science. However, they did not all necessarily

Table 1 Institutional case studies

\begin{tabular}{llllllr}
\hline Type of institution & $\begin{array}{l}\text { Pre-1992 } \\
\text { Russell group } \\
\text { (research- } \\
\text { intensive } \\
\text { institutions) }\end{array}$ & $\begin{array}{l}\text { Pre-1992 } \\
\text { Non-Russell } \\
\text { group }\end{array}$ & $\begin{array}{l}\text { Post-1992 (former } \\
\text { polytechnics) }\end{array}$ & $\begin{array}{l}\text { Post-2004 (former } \\
\text { colleges of higher } \\
\text { education) }\end{array}$ & Private & Total \\
\hline LFHE study & 2 & 1 & 0 & 3 & 1 & 7 \\
HEA study & 2 & 2 & 3 & 1 & 0 & 8 \\
Totals & 4 & 3 & 3 & 4 & 1 & 15 \\
\hline
\end{tabular}


work in the corresponding department, school, or faculty. The 34 'rank-and-file' staff in columns 3-5 were evenly divided between early and mid-career.

Of the 41 academic staff interviewed in the HEA study (columns 2-5 in Table 2), 30\% had entered from careers outside higher education. These included adult and community education, international development, business and industry, the armed services, research consultancy, and health and social care. Furthermore, nearly $50 \%$ of the 41 had close external links that were integral to their academic roles, with professional and disciplinary bodies; business and industry; professional practice; the Royal Colleges; government, regional, and community agencies; the UK National Health Service (NHS); charities; and international partners.

Of the 56 academic staff (columns 2-5 in Table 2), including middle managers, 32 were categorised as being itinerant. As shown in Table 3, though with the usual caveats about drawing firm conclusions from small numbers in a qualitative study, itinerant academics were in both early and mid-career, with a small majority in post-1992 institutions. A larger majority were formally categorised as being in teaching-only positions (although they may have undertaken pedagogic research and/or other allied activities), which is likely to be significant in that such staff generally aspired to obtain a teaching and research position, were not necessarily settled, and were more likely to have been on short-term contracts. The 32 were fairly evenly divided between disciplines. Perhaps surprisingly, slightly more were categorised as being mid-career than early career, demonstrating that this group of staff can also lack a sense of security and direction, even when they have an established post. Six middle managers (also categorised as mid-career) were characterised as itinerant, although four of these were in a private institution where a market-oriented environment possibly gave rise to a stronger sense that nothing could be taken for granted in terms of career futures. Generally speaking, those in middle management positions in both pre-and post-1992 institutions tended to feel more established and valued, and some were using the management route as a positive career step involving promotion, or the prospect of it.

Staff not characterised as itinerant were more likely to be in established posts and tended to be satisfied and settled with what they were doing, even if this focused on teaching as opposed to research. Some were clear that they wanted a less stressful life, particularly if they had a family, and others that because of caring responsibilities, health, or lifestyle issues, they wished to focus on a specific area of activity for the time being, but that this might change in future.

Table 2 Respondents in the two studies

\begin{tabular}{|c|c|c|c|c|c|c|c|c|}
\hline & $\begin{array}{l}1 \\
\text { Senior } \\
\text { managers } \\
\text { (e.g. pro- } \\
\text { vice- } \\
\text { chancellors/ } \\
\text { directors of } \\
\text { human } \\
\text { resources) }\end{array}$ & $\begin{array}{l}2 \\
\text { Middle } \\
\text { managers } \\
\text { (e.g. heads } \\
\text { of school } \\
\text { a } \mathrm{n} \mathrm{d} \\
\text { department) }\end{array}$ & $\begin{array}{l}3 \\
\text { Teaching } \\
\text { and } \\
\text { research } \\
\text { staff }\end{array}$ & $\begin{array}{l}4 \\
\text { Teaching- } \\
\text { only staff }\end{array}$ & $\begin{array}{l}5 \\
\text { Research- } \\
\text { only staff }\end{array}$ & $\begin{array}{l}6 \\
\text { Learning } \\
\text { enhancement } \\
\text { staff }\end{array}$ & $\begin{array}{l}7 \\
\text { Expert } \\
\text { witnesses and } \\
\text { commentators }\end{array}$ & $\begin{array}{l}8 \\
\text { Totals }\end{array}$ \\
\hline $\begin{array}{l}\text { LFHE } \\
\text { study }\end{array}$ & 22 & 15 & 0 & 0 & 0 & 0 & 16 & 53 \\
\hline $\begin{array}{l}\text { HEA } \\
\text { study }\end{array}$ & 14 & 7 & 9 & 19 & 6 & 7 & 4 & 66 \\
\hline Totals & 36 & 22 & 9 & 19 & 6 & 7 & 20 & 119 \\
\hline
\end{tabular}


Table 3 Distribution of those identified as itinerant academics

Employment category/status/institutional type

Numbers characterised as itinerant academics

$\begin{array}{ll}\text { Teaching and research } & 8 \\ \text { Teaching only } & 19 \\ \text { Research only } & 5 \\ \text { Early career } & 13 \\ \text { Mid-career } & 15 \\ \text { Late career } & 4 \\ \text { Middle management } & 6 \\ \text { Pre-1992 institution } & 12 \\ \text { Post-1992 institution } & 16 \\ \text { Private institution } & 4 \\ \text { Arts } & 11 \\ \text { Science (including engineering and health) } & 12 \\ \text { Social science (including business) } & 9\end{array}$

Therefore the studies represent a snapshot in time, and although it is not possible to make broad generalisations from the numbers involved, it is likely that they are indicative of trends.

Expert witnesses from the USA, Hong Kong, Australia, and Ireland were also consulted by telephone or Skype to verify the findings and provide an international dimension. These were senior higher education managers such as vice-chancellors, pro-vice-chancellors, heads of administration, and researchers with an international reputation in higher education studies. Conversations were conducted around the topic guide for senior managers and corroborated the fact that the linear apprenticeship model of academic careers was no longer universal. By 'drilling down' into the data, it was possible to explore individual stories that shed light on how individuals navigated the landscape in which they found themselves, and on what seemed to work for them. It became clear that there was a range of career pathways that were not precisely documented, but collectively represented significant fluidity between institutions and external settings. It was also apparent that a match between formal narratives, contained in, for instance, job descriptions, workload models, and annual review documentation; and day-today activities, relationships, and working patterns, could no longer be assumed. This enabled insights to be developed into what one respondent referred to as "lived reality".

Analysis of individual transcripts took place at three levels: the descriptive (for instance to identify movements across institutional boundaries), the interpretive (for instance to understand the relationship between formal employment policies and local interpretation of these), and the conceptual (for instance to review ways in which individuals are active agents in seeking and internalising new domains and ways of working). This process followed authors such as Creswell (1998) and Miles and Huberman (1994), enabling "semantic" (explicit, overt) and "latent" (underlying, implicit) themes to be identified (Braun and Clarke 2013).

\section{Being an itinerant academic}

Ideas about academic identity have developed from being seen as an essential core of distinguishing characteristics or values to which an individual subscribes, to a project over time in which identity grows and adapts through experience, to spatial definition drawn from the individual's interaction with structures and practices (Giddens 1991; Henkel 2000; Becher and Trowler 2001; Delanty 2008; Taylor 2008). Thus, McAlpine and Emmioglu (2015) see 
structures as representing "what is understood by an individual to be the career possibilities, including organizational hierarchies, workplace networks, intra-and inter-organizational mobility" (p. 1771). The idea that the individual is likely to be an active agent in defining their own role is now widespread across the literature on identities in higher education. Thus, Chen et al. (2015) "use agency to refer to individuals' motivations, intentions and efforts 'to plan, to construct a way forward given constraints (whether expected or unexpected)' (McAlpine et al. 2014: 958), while recognizing the influence of structural/systematic factors beyond their control (p. 1085)".

Pressure for additional space and time, for instance for research, has become evident (Gornall and Salisbury 2012; Leisyte 2016; Vostal 2016). As a result, "academics are striving for their own time. They try to get grants and sabbatical leaves, enabling them to get away from the demands of the home department, and in this way to create space and time for realising their research interests... One option... is to stay on the margins and to refuse to climb the career ladder" (Ylijoki 2013, pp. 250-1). However, the studies that are the subject of this paper suggest that another method for doing this is to look outside the institution for what might be seen as free space, in which individuals are less restricted by structural norms and expectations.

There was an overall sense among the narratives of individuals being exploratory, of trying out new skills, while accepting a degree of uncertainty and creating levers for further opportunities, therefore moving beyond the "symbolic compliance, professional pragmatism, and formal instrumentality" described by Teelken (2012, p. 278) or the "active manipulation" of structures described by Leisyte and Hosch-Dayican (2016, p. 225). They were not simply resisting or adapting structures, crossing or pushing boundaries, but moving outside the frame altogether, with acceptance of possible discontinuity, disruption, and risk. The intentionality associated with being an itinerant academic might therefore be said to represent a kind of escape valve or route, moving beyond a structural cage and the "ability to... modify or resist practices and expectations" (McAlpine and Amundsen 2011, p. 181). It may also represent a release from immediate pressures and contribute to an ability to cope and ultimately a sense of resilience, as well as to the fact that, notwithstanding well-documented pressures and even stresses, satisfaction with the profession remains high, so that "the majority of academics accommodate to features, which are in part viewed as questionable and dangerous, and altogether continue to consider their professional setting as satisfactory" (Teichler 2017).

In this situation, professional and career intelligence becomes critical as a step to the future. This is likely to be drawn from individually constructed networks - virtual, professional, and personal, that provide both support and stimulus in identifying potential opportunities. What it means to be an academic becomes less watertight as identities are reconstructed by individuals who see also themselves as entrepreneurs, partners, collaborators, and practitioners outside the institution, in an extended hinterland of activity as shown in Table 4.

These more fluid accounts of being an academic might be said to reflect emergent forms of cultural and social capital which are less elitist, more grounded in day-to-day activity, and more democratic and engaged. They tend to have currency with younger generations seeking knowledge enrichment and portability/transferability of experience. They also reflect the broader context of Kim's concept of "transnational capital", in which it is possible to "forge and sustain multistranded social relations, which makes it easy to move in and out of diverse groups and contexts" (Kim 2017, p. 988). 
Table 4 Classic accounts of and contemporary approaches to being an academic

\begin{tabular}{lc}
\hline Classic accounts of being an academic & Contemporary approaches to being an academic \\
\hline Discipline as key identifier & $\begin{array}{c}\text { Search for distinguishing activities in addition to } \\
\text { discipline } \\
\text { Partner and client orientation (co-practitioners, } \\
\text { professional bodies, business and community) }\end{array}$ \\
$\begin{array}{l}\text { Universally recognised career path involving } \\
\text { teaching, research, and knowledge exchange }\end{array}$ & $\begin{array}{c}\text { novel and/or unique to the individual, and time outside } \\
\text { higher education }\end{array}$ \\
Institutional/disciplinary patronage and mentors & $\begin{array}{c}\text { Extended networks inside and outside academia, } \\
\text { providing bottom-up support, information exchange, } \\
\text { within the profession providing guidance and } \\
\text { steerage }\end{array}$ \\
and intelligence about career possibilities \\
Disciplinary and professional capital & Knowledge and network capital \\
\hline
\end{tabular}

Thus, itinerant academics saw themselves as located in and having legitimacy in a wider environment:

I'd say it's much more around the other things you can do with your research, thinking about the ways in which findings from the research would feed through into changes in practice in... international development,... or more locally within the country and communities in which I'm working... (mid-career, social sciences, teaching and research oriented, pre-1992 institution).

Similarly, a health professional described how they had prioritised the development of new professional spaces via international networks in order to construct their own positioning and legitimacy as an academic:

... I had a mentor in motivational design and systems thinking in [the US]. I had an expert in health research here..., I had a technology expert... And it worked extremely well for me... I had a team, a very diverse team, a team that was outside this university but the hub of it was here... I think the other turning point has got to be my experience [at a professional body]. And that's because that's where I moved from being a researcher to... understanding the bigger context, understanding how politics influence research, how strategy is extremely important; the global aspect of research... (mid-career, health sciences, research oriented, post-1992 institution).

Itinerant academics saw mobility across other spheres as enriching both the inherent interest of their work and what they were able to offer their institutions, as well as providing a potential safety net if their position became insecure. Five of the individuals in the studies had more than one employer, so effectively had portfolio careers, and one person found that the stimulus boosted their prospects, despite less security at the time:

... [I was] managing a portfolio of doing these different pieces of work for different employers, at different points in time... There's risk in it, personal risk in it, but I think that [possibility] does exist (mid-career, health sciences, research oriented, post-1992 institution).

Although a preponderance of such individuals was found among those with practice links, as in the above quotations from the respondent narratives, it was also evident that the trends described could be found across the spectrum of disciplines. Although it might be expected 
that those in the scientific and social science communities might have more opportunities for work focused outside the university, a small majority of people doing this in the studies were in arts and humanities subjects, such as the following person:

although I would introduce myself as an 'academic', I'm not sure... I think I'm kind of increasingly happy with the term 'entrepreneur' actually because I'm a Director of a social enterprise in the city as well and I do a lot of work for them for no money and our projects raise money to do good stuff... (mid-career, humanities, teaching and engagement, pre-1992 institution).

Nor was this restricted to institutions with a strong applied or regional orientation, as might be expected in post-1992 institutions. The individuals involved in external activity ranged from people who did it in their own time, paid or otherwise, people who undertook it with the tacit agreement of a line manager although it was not in their formal job description, and people who had part-time contracts and were formally employed by other external bodies. However, what was significant was that individuals saw external interests as a key aspect of their day-today existence. These were in addition to outward facing roles required by institutions such as "promotion and outreach, consultancy, marketing, commercialisation" Brew et al. (2018, p. 7).

Extended activity has always been a part of academic life. However, there would appear to have been a step change in the last few years in response to contemporary triggers such more market-oriented environments, less availability of teaching and research posts, and the portfolio approach of younger age groups to work, often to accommodate childcare and dual careers. What has been less recognised is the extent of this and ways in which it is also being seen as a possible point of departure, either as a route to more interesting and rewarding work or as a backup if the academic career, for whatever reason, ends. The term itinerant academic therefore reflects not only physical and intellectual mobility, but an openness to options outside higher education that might as yet be unknown and untried.

\section{Identity typology of itinerant academics}

The following extended narrative from an individual with an engineering background demonstrates the range of motivations driving the itinerant academic. These include a desire for personal autonomy, job satisfaction, career development, and back up, as well as a frustration with institutional structures and processes (key phrases italicised):

... I struggle to see my career developing at xxx and it's there almost as a fallback option if other things I'm working on don't work out, if the business doesn't work out... At the moment it's a job to pay the bills. I've basically been told that if I want to I can grow my own team within the existing team and there are career paths there, but I think the day-today work just gets in the way of that..., and I've got no huge incentive to become institutionalised in a university in the way that I was in my previous employ[ment]... I think the whole bureaucracy of the university is something that I think generally holds people back there... Because I only do two days a week I feel it's quite a relief when I'm not there, when I'm actually working for myself, when I'm my own boss for two and a half days a week, effectively... You have far greater control and you don't feel you've got several tiers of management up above you... I've got to a point now where, especially through having my own business, that there's plenty of other work... I think if you were 
relying on the university to advance your career, to provide you with a rope to pull you up the wall, it's not going to happen... I'm quite lucky that because I move around in several different circles I feel quite well connected, so don't feel quite as trapped as probably I would... (mid-career, civil engineering, research oriented, part-time, post-1992 institution).

In this case, the individual concerned had wide-reaching networks into business and industry, and worked part-time so that they could run their own business. Their account illustrates an ambivalence between the institution as safe haven and as a structure that imposes limitations on developing more creative or even speculative types of activity, with a delicate balance between feeling secure and feeling restricted by structural factors (referred to in this case as "bureaucracy"). The narrative therefore illustrates a need to satisfy what might be termed both a spirit of exploration and a sense of security, also pointing to the significance of personal and professional networks in achieving these aims. These motivations were not mutually exclusive and could overlap and change according to a person's circumstances. Each individual may have their own tipping point at which security of employment is seen as restriction rather than a motivating factor.

As shown in Table 5, those motivated by a spirit of exploration tended to be driven by a belief in the value of new ventures and a desire to accumulate experience, although this was not necessarily oriented towards specific goals. It was therefore aspirational in a way that went further than simple ambition. Being open to possibilities, even if it is not apparent that they are immediately relevant, incorporated a belief that development will follow "if you show you're dedicated and keen and you do good stuff..." (mid-career, applied science, teaching and engagement, post-2004 institution). At the same time, individuals tended to seek milieux that would enable them to build opportunity:

I'm a member of this trade body, so I go to quarterly meetings and that's a network... across Europe, so that for me is really important in terms of networking, in terms of finding out what EU funding is going to be available... of finding project partners and finding out what the new trends are in our domain (early career, humanities, research only, post-2004 institution).

Again, external connection with, in this case, a trade body was the catalyst for making practical links, but also colleagueship and motivation. Moreover, such an approach may involve a sense of regaining some of the freedom, autonomy, and indeed control that may have been felt to have been lost in more regulated institutional contexts and performance-driven environments.

Contributing to a sense of security was the idea that spreading one's sources of expertise and contacts could protect against future uncertainty and risk, and that one could not afford to

Table 5 Identity typology of itinerant academics

\begin{tabular}{|c|c|c|c|}
\hline Motivations & Values & Connections & Careers \\
\hline $\begin{array}{l}\text { Spirit of } \\
\text { exploration }\end{array}$ & $\begin{array}{l}\text { Autonomy } \\
\text { Freedom }\end{array}$ & $\begin{array}{l}\text { Spaces outside discipline/higher } \\
\text { education including private } \\
\text { sector } \\
\text { External networks as bridge } \\
\text { to new opportunities }\end{array}$ & $\begin{array}{l}\text { Multiple and possibly parallel } \\
\text { career paths over time and } \\
\text { across sectors } \\
\text { Distinctive and unique }\end{array}$ \\
\hline $\begin{array}{l}\text { Sense of } \\
\text { security }\end{array}$ & $\begin{array}{l}\text { Work/life balance } \\
\text { Service (students, } \\
\text { community) }\end{array}$ & $\begin{array}{l}\text { Spaces likely to be connected to } \\
\text { professional practice } \\
\text { External networks as support structure }\end{array}$ & $\begin{array}{l}\text { Career initiatives likely to } \\
\text { reinforce existing connections } \\
\text { and experience }\end{array}$ \\
\hline
\end{tabular}


stand still. This included hedging bets so as to secure more potential avenues of employment and protect against unforeseen events. Thus:

I do A-Level marking as well because that's kind of, well I might not need to do it now, but it was another string to the bow (early career, learning support, post-2004 institution).

Others simply wanted to maintain professional allegiances, and therefore external credibility, for instance with a professional body, even though these might not bring immediate credit within their institution:

I'm currently trying to fill in my paperwork to become a Chartered Engineer, so that's a fairly standard thing for most practising engineers to do and that's always an interesting one in academia because not every engineering department really promotes it or pushes it, because in many ways it's not necessary... (mid-career, engineering, teaching oriented, pre-1992 institution).

The motivations at each end of the exploration/security continuum are likely to play out in practice via pragmatism and negotiated solutions, and to be driven by a cost benefit analysis of effort and likely reward:

I'd either think about seeing if there were opportunities within the university for something different, a bit more 9 to 5 maybe, so that I could have a life without feeling guilty, or... leaving higher education altogether and maybe go into teaching something else... It just means I'm weighing this as a long-term career option (mid-career, civil engineering, research oriented, part-time, post-1992 institution).

Some, like the following individual with a young family and long commute, took account of work-life balance in making a decision about applying for a promoted post, preferring to stay in a situation in which they felt secure, rather than take on new responsibilities. Personal commitments, including health and well-being, could therefore be said to represent another external space:

I seriously looked at it [academic management post] and I thought, 'Actually, my quality of life is going to be better' [if I don't go for it]. My aspirations... I want to do the National Teaching Fellowship, I want to write more and more broadly about teaching and learning in academia... I'm more interested in wellbeing and happiness... (midcareer, humanities, teaching and research, post-1992 institution).

This also reflects findings by McAlpine et al. (2014):

Our findings, highlighting a range of powerful and shifting non-academic elements and intentions in individuals' work lives, demonstrate the need for greater attention to the influence of the personal arena when explaining engagement in academic work (p. 959).

Rather than necessarily "deciding whether to leave the academy or remain" (McAlpine et al. 2014), therefore, there is a sense in which itinerant academics are testing options, including the option of "leaving", for instance via secondments or the incorporation of external work into day-to-day schedules, while "remaining" for the time being. There is therefore an element of provisionality about their identities, in which they are exercising agency not only by interacting with structures such as preordained career pathways, but also engaging with and gaining credibility vis-à-vis alternatives. There was also a sense in which itinerant academics 
were both acquiring and building social capital at the same time. More specifically, a process arises whereby undertaking a new type of activity, in a new setting, informs career possibilities and indeed new aspects of identity. Thus, action might be said to determine aspiration as well as the other way round. This is particularly relevant in contemporary environments in which careers are no longer necessarily pre-determined, and individuals are not simply making choices about which pathway to take, but are themselves creating and testing out new pathways in what may be complex situations. Those with professional, practice, and community links outside higher education tended to have more opportunity to do this, but itinerant academics were by no means confined to practice subjects, or indeed to those on academic as opposed to professional contracts, such as those in learning support.

\section{Field and habitus associated with the itinerant academic}

The studies suggest that itinerant academics are less accepting of established structures (in Bourdieu's terms, in the academic field) and are more likely to develop a new habitus, that is the individual's interaction with the structures and power relations of the field, by entering and engaging with fields external to higher education. They therefore remove themselves in different degrees from what Bourdieu (1993) terms "cultural reproduction" within the academic field, for instance in the form of patronage by senior staff, clear-cut career paths, and strong disciplinary bases. Depending on their relationship with a new field, for instance whether this is on a salaried, self-employed, or voluntary basis, they will in turn begin to interact with and be influenced by new structures and cultures. At the same time, a general democratisation and flattening of social structures, in particular via the influence of social media, has challenged the application of Bourdieu's theories by highlighting the emphasis placed on engagement activity as opposed to aspiring to elite values and a sense of exclusivity (Coulangeon and Duval 2015). This is in turn reflected in contemporary attitudes to professionalism which are less hierarchical, with greater openness to external influences where new forms of capital may accrue (Whitchurch 2013). These forms of capital may however be less certain and more subject to change, with a looser connection to established disciplines or institutions. Therefore their credibility in an academic setting is likely to be variable and to depend on the individual's ability to establish legitimacy on the basis of the perceived value-added of a unique set of experience and skills.

In the same way that Marginson, drawing on Bourdieu (1993), describes "position taking" by institutions within international league tables and markets (Marginson 2008, p. 307), individuals are also involved in position taking within higher education institutions. As institutional requirements have become more stringent, it could be said that individuals have become more constrained in their "position taking", and their perception of what might be available to them, and therefore look at what might be possible in other fields (in which their links with academia might well give them status and a head start in position taking). Over time, such individuals may come to influence the academic field and its power relations, by using what Marginson terms "creative imagination" (p. 312).

Furthermore, at the micro level, those on mainstream teaching and research contracts might be said to be more locked into traditional university structures and benefit from them by understanding and positioning themselves appropriately within hierarchies and power structures, whereas those with more diverse backgrounds and expectations are more likely to seek and occupy other fields and develop a habitus within them. The itinerant academic might therefore be said to be associated with Coulangeon and Duval's concept of "emergent cultural 
capital" (Coulangeon and Duval 2015) representing new forms of knowledge peripheral to or disconnected from an academic discipline, likely to be acquired via external links and extended networks. The opportunities of acquiring both have been significantly enhanced by social media, which would appear to be a critical aspect of building and extending opportunity.

\section{Implications and conclusions}

The studies suggest that despite an international literature on changing patterns in contractual arrangements, less attention has been paid to ways in which individuals themselves are adapting to less certain environments, in which institutional structures and processes cannot necessarily be relied upon to future-proof an individual's career. Alongside this is the fact that despite efforts by senior managers to introduce new career structures, such as a teaching track to the level of professor, the belief is that it is research that really counts. Issues of credibility permeated the narratives, so that individuals saw a need to reinforce their position on an ongoing basis, particularly (but not necessarily) if they did not have a contract that formally included research. Other, including external, activities are therefore being brought into play, and it could be said that individuals are in this way mirroring changing institutional roles, in particular interaction with social and community agendas. Therefore, being a contemporary academic is not a static concept, even to maintain an individual's status quo. This is in addition to whatever actions or achievements might be required to progress up the career ladder. However, new forms of activity may not conform to institutional expectations about what is 'legitimate', and itinerant academics may develop a kind of dual identity, one for the purposes of their institution and one for the purpose of a developing interest and/or a safety net. Thus, on the one hand, people work "more to the book" (learning support academic, post-1992 institution) in order to obtain credit via workload models, while on the other hand seeking other activities to compensate for a possible loss of autonomy and perceived legitimacy.

There would therefore appear to be a mismatch between structures and processes intended for those on a mainstream teaching and research career track, and the lived experience and expectations of academic staff in different types of role. In practice, there may be more overlap and extension across activities than formal classifications of roles would suggest, so that distinctions between academic staff on the basis of employment categories have become increasingly artificial. One senior researcher in higher education who was consulted referred to this mismatch as the difference between "instrumentalities" and "realities", pointing to the need for an ongoing critique of "romantic" notions of being an academic.

A paradox remains of individual commitment to higher education per se, including service to students and the excitement of research, alongside frustrations and, at times, perceived structural impediments. This distinguishes itinerant academics from those in "boundaryless career[s]" (Arthur and Rousseau 1996; Dowd and Kaplan 2005), whereby employees move from employer to employer, in that itinerant academics are likely to experience other milieux via consultancies, professional body activity, and community engagement, at the same time as being employed in higher education. There was therefore less evidence of building a portfolio in order to 'sell oneself on' to another employer, possibly for a higher price, than a general awareness of needing to be more proactive in maintaining a career in higher education than in the past. In fact, salaries did not feature as a critical aspect of career development. Being itinerant was, therefore, more with the aim of regaining some control of possible futures, reinforcing capability and credibility, and enriching a future academic career, in acknowledgement that this might take a different, less linear 
or certain form than in the past. It was therefore about negotiating current structures and processes, at the same time as optimising future possibilities, while remaining anchored within higher education as the favoured (though maybe not the sole) work locale. Being itinerant therefore implies psychological as much as physical mobility. The studies also demonstrated an ongoing cost-benefit analysis, though not necessarily financial, by individuals who weighed the attraction of an academic career with the risks.

There may be implications for the labour market in that it would appear that increasing numbers of people, even those in so-called permanent contracts, feel that they have less expectation of a secure future. Those who have added to their portfolios in creative and inventive ways, and are frustrated with a lack of progression, may have more possibilities for alternative employment than hitherto. This could leave institutions with an ageing profile of individuals who are not making an optimal contribution. Nevertheless, there is also evidence of individuals with specific skills, particularly in professional areas, joining higher education at a later stage. Roles are also emerging, for instance in the organisation of learning support, the development of doctoral schools and research engagement, that are attractive to people with $\mathrm{PhDs}$ who wish to continue to work in higher education, and crossovers are occurring, creating greater fluidity in academic environments and identities as individuals interact with and modulate institutional structures and processes.

Although there was recognition from senior managers of a diversification of the workforce, this tended to be at the macro level, with structural solutions being proposed such as a broader range of contracts. The latter particularly could include units that were expected to deliver selffunding programmes, so that staff might have a series of part-time appointments in more than one institution. It may therefore be that the phenomenon of the itinerant academic is more likely to arise in institutions that adopt a more market-oriented approach, and/or where aspects of institutional activity (such as language teaching) are outsourced. This in turn is likely to be influenced by government funding regimes and the existence of private institutions. Thus, in Hong Kong, it was clear that market-oriented approaches, in which individuals might work part-time for different institutions and even sectors, fostered an itinerant approach. As described by a senior member of a university there, this had led to a "new breed" of academics. Nevertheless, the studies suggested that even in publicly funded institutions, individuals did not take their current positions for granted and felt the need to have possible alternative avenues. Furthermore, a more open-ended approach to careers may be easier for younger staff who are less likely to compare present conditions with a more settled past and are able to hold in mind the possibility of alternative approaches. It was also clear that the role of middle managers in facilitating opportunities and flexing processes on a bespoke basis appeared to be more significant to individuals than adjustments that were made to formal structures.

Thus, institutions are seeking more flexible contractual arrangements to enable them to respond more rapidly to changing demand, and individuals are seeking ways of enhancing their working lives, creating opportunities and securing their futures, in a top-down, bottom-up dynamic. Each individual is likely to be driven by a mix of aspiration, intrinsic interest, and a need for security in different measures at different times in their career and according to local circumstances. Of the early and mid-career staff interviewed, some said that security of employment was a priority, often because of family responsibilities (if only for the time being) at the expense of a career-enhancing, but possibly risky, move; others took a more exploratory approach, convinced that it would be productive to add to their portfolio and diversify, being willing to accept some immediate risk in the belief that it could ultimately provide greater security. These approaches were not mutually exclusive. A sense of investment for the future 
also comes into play, even though precise dividends cannot be calculated. Thus, assumptions about the 'ideal' scenario of one or two postdoctoral appointments leading to an academic career are breaking down, and careers have become less positional. The projects described suggest that individuals are not only responding to and interacting with structures, but also finding satisfaction and solace outside them. The rise of the itinerant academic might be seen as a reaction or even antidote to increasingly stringent structural requirements, in the form of, for instance, workload models and performance assessment, with a sense of needing to have more control over the future, perhaps compensating for a perceived reduction in academic autonomy. For institutions, there is also a delicate balance to consider between maintaining a secure environment and being seen as restrictive. The developments described in this paper, therefore, are likely to continue to raise questions about what it means to be 'an academic', and how this might be changing.

Acknowledgements The author wishes to thank Professor Rosemary Deem, Steve Woodfield, and two anonymous referees for their helpful comments on earlier versions of this paper.

Funding The studies referred to in this paper were funded by (a) the UK Leadership Foundation for Higher Education, on Staffing Models and Institutional Flexibility (Whitchurch and Gordon 2013a, b), and (b) the UK Higher Education Academy, on Shifting Landscapes: Meeting the Staff Development Needs of the Changing Academic Workforce (Locke et al. 2016).

\section{Compliance with ethical standards}

Conflict of interest The author declares that she has no conflict of interest.

Open Access This article is distributed under the terms of the Creative Commons Attribution 4.0 International License (http://creativecommons.org/licenses/by/4.0/), which permits unrestricted use, distribution, and reproduction in any medium, provided you give appropriate credit to the original author(s) and the source, provide a link to the Creative Commons license, and indicate if changes were made.

\section{References}

Arthur, M. B., \& Rousseau, D. M. (Eds.). (1996). The boundaryless career. New York: Oxford University Press.

Becher, T., \& Trowler, P. (2001). Academic tribes and territories: intellectual enquiry and the culture of disciplines. Buckingham: SRHE/Open University Press.

Bourdieu, P. (1993). The field of cultural production. Cambridge: Polity Press.

Braun, V., \& Clarke, V. (2013). Successful qualitative research: a practical guide for beginners. London: Sage.

Brew, A., Boud, D., Lucas, L., \& Crawford, K. (2018). Academic artisans in the research university. Higher Education, 76(1), 115-127.

Cavalli, A., \& Moscati, R. (2010). Academic systems and professional conditions in five European countries. European Review, 18(Supplement 1), 35-53.

Chen, C., McAlpine, L., \& Amundsen, C. (2015). Postdoctoral positions as preparation for desired careers: a narrative approach to understanding postdoctoral experience. Higher Education Research \& Development, 34(6), 1083-1096.

Coates, H., \& Goedegebuure, L. (2010). The real academic revolution. Melbourne: L. H. Martin Institute.

Coulangeon, P., \& Duval, J. (2015). The Routledge companion to Bourdieu's 'distinction'. NewYork: Routledge.

Courtois, A., \& O'Keefe, T. (2015). Precarity in the ivory cage: neoliberalism and casualisation of work in the Irish higher education sector. Journal for Critical Education Policy Studies, 13(1), 43-56.

Creswell, J. (1998). Qualitative inquiry and research design: choosing among five traditions. Thousand Oaks: Sage Publications. 
Deem, R. (2016). Conclusion. In L. Leisyte \& U. Wilkesmann (Eds.), Organising academic work in higher education: teaching, learning and identities (pp. 262-267). New York: Routledge.

Delanty, G. (2008). Academic identities and institutional change. In R. Barnett \& R. di Napoli (Eds.), Changing identities in higher education: voicing perspectives (pp. 124-133). Abingdon: Routledge.

Dowd, K. O., \& Kaplan, D. M. (2005). The career life of academics: boundaried or boundaryless? Human Relations, 58(6), 699-721.

Finkelstein, M. J., Conley, V. M., \& Schuster, J. H. (2016). The faculty factor. Reassessing the American academy in a turbulent era. Baltimore: Johns Hopkins University Press.

Florida, R. (2010). The great reset: how new ways of living and working drive post-crash prosperity. New York: HarperCollins.

Florida, R. (2012). The rise of the creative class. New York: Basic Books.

Galaz-Fontes, J., Arimoto, A., Teichler, U., \& Brennan, J. (Eds.). (2016). Biographies and careers throughout academic life. Cham: Springer.

Giddens, A. (1991). Modernity and self-identity: self and society in the late modern age. Cambridge: Polity Press.

Gornall, L., \& Salisbury, J. (2012). Compulsive working, 'hyperprofessionality' and the unseen pleasures of academic work. Higher Education Quarterly, 2(66), 135-154.

Henkel, M. (2000). Academic identities and policy change in higher education. London: Jessica Kingsley.

Jones, G., Weinrib, J., Metcalfe, A., Fisher, D., Rubenson, K., \& Snee, I. (2012). Perceptions of early career faculty and the academic workplace in Canada. Higher Education Quarterly, 66(2), 189-206.

Kehm, B., \& Teichler, U. (Eds.). (2013). The academic profession in Europe: new tasks and new challenges. Dordrecht: Springer.

Kezar, A., \& Maxey, D. (Eds.). (2016). Envisioning the faculty for the twenty-first century: moving to a missionoriented and learner-centered model. New Brunswick: Rutgers University Press.

Kim, T. (2017). Academic mobility, transnational identity capital, and stratification under conditions of academic capitalism. Higher Education, 73, 981-997.

Kweik, M. (2012). Knowledge production in European universities: states, markets and academic entrepreneurialism. Oxford: Peter Lang.

Lama, T., \& Jouille, J. E. (2015). Casualization of academics in the Australian higher education: is teaching quality at risk? Research in Higher education Journal, 28, 1-11.

Leisyte, L. (2016). Bridging the duality between universities and the academic profession: a tale of protected spaces, strategic gaming, and institutional entrepreneurs. In L. Leisyte \& U. Wilkesmann (Eds.), Organising academic work in higher education: teaching, learning and identities (pp. 55-67). New York: Routledge.

Leisyte, L., \& Hosch-Dayican, B. (2016). Boundary crossing and maintenance among UK and Dutch bioscientists: towards hybrid identities of academic entrepreneurs. In L. Leisyte \& U. Wilkesmann (Eds.), Organising academic work in higher education: teaching, learning and identities (pp. 223-242). New York: Routledge.

Locke, W., Whitchurch, C., Smith, H., \& Mazenod, A. (2016). Shifting landscapes: meeting the staff development needs of the changing academic workforce. York: Higher Education Academy.

Machado-Taylor, M., Soares, V. M., \& Teichler, U. (Eds.). (2017). Challenges and options: the academic profession in Europe. Dordrecht: Springer.

Marginson, M. (2008). Global field and global imagining: Bourdieu and worldwide higher education. British Journal of Sociology of Education, 29(3), 303-315.

McAlpine, L., \& Amundsen, C. (2011). Making meaning of diverse experiences: constructing an identity through time. In L. McAlpine \& C. Amundsen (Eds.), Doctoral education: research-based strategies for doctoral students, supervisors and administrators (pp. 173-183). Heidelberg: Springer.

McAlpine, L., \& Emmioglu, E. (2015). Navigating careers: perceptions of sciences doctoral students, post-PhD researchers, and pre-tenure academics. Studies in Higher Education., 40(10), 1770-1785.

McAlpine, L., Amundsen, C., \& Turner, G. (2014). Identity-trajectory: reframing early career academic experience. British Educational Research Journal, 40(6), 952-969.

Meek, V. L., Goedegebuure, L., Santiago, R., \& Carvalho, T. (Eds.). (2010). The changing dynamics of higher education middle management. Dordrecht: Springer.

Miles, M., \& Huberman, M. (1994). Qualitative data analysis. London: Sage Publications.

Moynagh, M., \& Worsley, R. (2009). Changing lives, changing business: seven life stages in the 21st century. London: A \& C Black.

Musselin, C. (2013). Redefinition of the relationships between academics and their university. Higher Education, $65(1), 25-37$.

Taylor, P. (2008). Being an academic today. In R. Barnett \& R. di Napoli (Eds.), Changing identities in higher education: voicing perspectives (pp. 27-39). Abingdon: Routledge.

Teelken, C. (2012). Compliance or pragmatism: how do academics deal with managerialism in higher education? A comparative study in three countries. Studies in Higher Education, 37(3), 271-290. 
Teichler, U. (2017). Academic profession, higher education. In J. C. Shin \& P. Teixeira (Eds.), Encyclopaedia of international higher education systems and institutions (pp. 1-6). Dordrecht: Springer.

Teichler, U., \& Cummings, W. (Eds.). (2015). Forming, recruiting and managing the academic profession. Dordrecht: Springer.

Viale, R., \& Etzkowitz, H. (Eds.). (2010). The capitalization of knowledge: a triple helix of university-industrygovernment. Cheltenham: Edward Elgar.

Vostal, V. (2016). Accelerating academia: the changing structure of academic time. London: Palgrave Macmillan.

Whitchurch, C. (2013). Reconstructing identities in higher education: the rise of third space professionals. New York: Routledge.

Whitchurch, C., \& Gordon, G. (2013a). Staffing models and institutional flexibility. London: Leadership Foundation for Higher Education.

Whitchurch, C., \& Gordon, G. (2013b). Staffing models and institutional flexibility: literature review. London: Leadership Foundation for Higher Education.

Whitchurch, C., \& Gordon, G. (2017). Reconstructing relationships in higher education: challenging agendas. New York: Routledge.

Wilkinson, A., Hislop, D., \& Coupland, C. (2016). Perspectives on contemporary professional work: challenges and experiences. Cheltenham: Edward Elgar Publishing.

Ylijoki, O.-H. (2013). Boundary-work between work and life in the high-speed university. Studies in Higher Education, 38(2), 242-255. 